\title{
Applications of Cone Beam Computed Tomography in Endodontics: A Review
}

\section{Meena $\mathrm{N}^{*}$ and Kowsky RD}

Department of Conservative Dentistry and Endodontics, V.S. Dental College, Bangalore, India

\begin{abstract}
Aim: This review aims to provide comprehensive information related to the principles of Cone beam computed tomography and its potential applications in the management of various endodontic conditions.

Methodology: A thorough and extensive electronic literature search was conducted utilizing PubMed, for articles related to endodontic applications of CBCT published during the period between January 2005 and September 30, 2013. Search words such as 'principles of CBCT', 'endodontic applications of CBCT' were employed to obtain information. Only those articles dealing with the principles and various endodontic applications of CBCT are included in this review.

Results: The search revealed 258 articles, 70 of which were found to be relevant to the scope of this review and were used in this review CBCT is a revolutionary and innovative procedure that has changed the paradigms in the management of various endodontic conditions. The information provided by this tool-three dimensional view of anatomic and pathologic structures, ability to provide details of root and canal anatomy, assessment of dento-alveolar trauma, assessment of root resorptions, etc. has contributed substantially to its extensive utilization in a short period of time.

Clinical Significance: CBCT can be used in the management of a variety of conditions like dento-alveolar truma, root resorptions, early apical periodontitis, roots and canals with unusual anatomy, dental anomalies, etc. The effective dose of CBCT (focused field of view) varies from 5-38.3 $\mu \mathrm{Sv}$. The effective dose of intra-oral periapical radiographs and panoramic radiographs are $<8.3 \mu \mathrm{Sv}$ and 9-26 $\mu \mathrm{Sv}$ respectively. Thus CBCT has an effective dose in the similar range of magnitude as other dental radiographs, but, its three dimensional imaging capability and $100 \%$ sensitivity (1.0) and specificity (1.0) makes it an invaluable tool in the field of endodontics.
\end{abstract}

Keywords: Cone-beam computed tomography; Imaging; Threedimensional; Root resorption; Tooth fractures; Periapical periodontitis; Anatomic variation

\section{Introduction}

Cone Beam Computed Tomography (CBCT) is an extra-oral imaging system specifically designed for three dimensional imaging of the oral and maxillofacial structures. Most of the limitations associated with conventional radiography like compression of a three dimensional object into a two dimensional image, image distortion, anatomic superimposition, are overcome with cone beam computed tomography (CBCT). CBCT produces clear images with higher resolution at a reduced radiation and lower cost when compared to medical CT [1]. It is a more compact, faster and safer version of the medical CT. The time needed for a full scan is typically under one minute and the radiation dosage is several times lesser than that of a CT scanner. The purpose of this article is to provide an overview of the associated principles, applications and advantages of CBCT in the management of various endodontic conditions. In order to provide a better understanding regarding the usefulness of this imaging system, СBCT images obtained for the management of various endodontic conditions are discussed.

\section{Methodology}

A thorough and extensive electronic literature search was conducted utilizing PubMed, for articles related to endodontic applications of CBCT published during the period between January 2005 and September 30, 2013. Search words such as 'principles of CBCT', 'endodontic applications of CBCT' were employed to obtain information. Only those articles dealing with the principles and various endodontic applications of CBCT are included in this review. In order to obtain information that is clinically relevant, only those articles on human investigation were selected, and animal investigations and studies like those performed on acrylic block, etc were not included in this review.

\section{Result}

The search revealed different kinds of paper dealing with various applications of CBCT in Endodontics. Among the 258 articles revealed, 70 were found to be relevant to the scope of this review and were used in this review. Among the 70 relevant articles, 31 were case report, 21 were in vivo studies, and 18 were ex vivo studies.

Analyzing these articles, it appears that CBCT being three dimensional is an effective tool in the diagnosis and management of conditions like early apical periodontitis tooth with complex anatomy, root fracture, root resorption, periradicular surgical planning, dental anomalies. Utilization of this imaging technology in appropriate conditions may result in accurate diagnosis and predictable management.

\section{Discussion}

Correct diagnosis is the key in the management of any pathologic

${ }^{*}$ Corresponding author: Dr. N Meena, MDS, Professor, Department of Conservative Dentistry and Endodontics, V.S. Dental College, Bangalore, India Tel: +919845153495; E-mail: mndrmeena@gmail.com

Received May 08, 2014; Accepted June 18, 2014; Published June 20, 2014

Citation: Meena N, Kowsky RD (2014) Applications of Cone Beam Computed Tomography in Endodontics: A Review. Dentistry 4: 242. doi:10.4172/21611122.1000242

Copyright: $\odot 2014$ Meena N, et al. This is an open-access article distributed under the terms of the Creative Commons Attribution License, which permits unrestricted use, distribution, and reproduction in any medium, provided the original author and source are credited. 
condition. Imaging aids in visualizing internal structures that would be unseen otherwise. $\mathrm{CBCT}$ is a relatively new, three dimensional modality that can be useful in managing various endodontic conditions. In the following section basic principles of CBCT will be reviewed followed by a comprehensive review on condition wise application of CBCT in endodontics.

\section{Principles of CBCT}

Aria et al. from Japan [2] and Moshiri et al. from Italy [3] are credited with the development of CBCT scanners for use in oro-facial imaging. Unlike medical CT which employs a fan shaped beam of $\mathrm{X}$-ray, CBCT projects a cone or pyramid shaped X-ray beam. Patient positioning during imaging varies, it can be supine, standing, or sitting based on the system manufacturer. CBCT units can be categorized into two types. One type of unit has Charge-Coupled Device (CCD) detector and the other utilizes Flat Panel Imager (FPI). Basically, the $\mathrm{X}$-ray source and the scanner makes a full $\left(360^{\circ}\right)$ or half rotation $\left(180^{\circ}\right)$ around the patient's head. While doing so a cylindrical volume of data known as field of view is captured. This data is then analyzed by sophisticated software to display images in various planes. Hard copies of the images can be obtained through a printer connected to the computer. These images can be transferred to a compact disc (CD) or other portable memory devices and can also be mailed electronically to other clinicians for consultation and discussion purposes.

CBCT systems can be categorized according to the available Field Of View (FOV) or selected scan volume height as follows [1]:

Localized region: approximately $5 \mathrm{~cm}$ or less (eg, dentoalveolar, temporomandibular joint)

Single arch: $5 \mathrm{~cm}$ to $7 \mathrm{~cm}$ (eg, maxilla or mandible)

Interarch: $7 \mathrm{~cm}$ to $10 \mathrm{~cm}$ (eg, mandible and superiorly to include the inferior concha) Nasion)

Maxillofacial: $10 \mathrm{~cm}$ to $15 \mathrm{~cm}$ (eg, mandible and extending to

Craniofacial: greater than $15 \mathrm{~cm}$ (eg, from the lower border of the mandible to the vertex of the head)

\section{Radiation Dosage}

Much like conventional radiography, CBCT utilizes ionizing radiation. There is a misconception among the general population and probably even among the dental professionals that CBCT exposes individuals to very high amount of radiation. Even though CBCT produces more radiation than conventional radiography, the difference is at best marginal. On the other hand, radiation emitted in CBCT imaging is several times lower than medical fan beam CT imaging. Not all CBCT units produce the same dose of radiation. The same CBCT unit may produce different amount of radiation depending on the field of view (focused or large), power settings, rotation around head $\left(180^{\circ}\right.$ or $\left.360^{\circ}\right)$, etc. The effective dose of one CBCT unit (3D Accuimoto, J Morita, Kyoto, Japan) has been reported to be equivalent to two or three standard periapical radiographic exposures [2].

Note that the effective dose of CBCT is almost similar to that of panoramic radiograph and equivalent to a few periapical radiographs, whereas it is several times lower than medical fan beam CT (Table 1).

\section{Accuracy of CBCT}

Scientific literature suggests that CBCT is more accurate than

\begin{tabular}{|l|c|}
\hline Imaging & Effective dose $\boldsymbol{\mu S v}$ \\
\hline Intra oral radiograph & $<8.3$ \\
\hline Panoramic & $9-26$ \\
\hline Cephalometric radiograph & $3-6$ \\
\hline Cone beam CT( focused field of view) (dento-alveolar) & $5-38.3$ \\
\hline Full mouth series radiograph & $35-388$ \\
\hline Cone beam CT-Craniofacial & $68-599$ \\
\hline Medical fan beam CT-maxilla and mandible & 2000 \\
\hline
\end{tabular}

Table 1: Comparison of effective radiation dosage among Cone beam CT, conventional radiography and Medical fan beam CT $[3,4]$.

radiography in imaging anatomic as well as pathologic dento-facial structures. Studies have shown the CBCT to be accurate and reliable in detecting apical periodontitis, vertical root fracture, resorptive defects. CBCT also provides a better view of root and pulp canal anatomy when compared to radiography. For example, presence of buccolingual curvature in a root is most often missed by radiographs, but it can be easily detected in CBCT image. Most often radiographs provide little or no information about the presence of additional canals, their shape and curvature. However CBCT imaging will reveal the same findings with high accuracy. In the following sections, accuracy of CBCT in detecting various endodontic conditions will be discussed along with representative cone beam computed tomographic images.

\section{Detection of Apical Periodontitis}

Apical Periodontitis can be detected at an early stage using CBCT when compared to conventional radiographs. It appears that conventional radiography results in an under-estimation of the incidence of apical periodontitis [3-5]. Lesion confined within the cancellous bone cannot be detected by conventional radiographs, whereas they are easily detected in CBCT which captures images in slices thereby avoiding anatomic superimposition. Lofthag-Hansen et al. [6] compared the periapical status of 46 posterior mandibular and maxillary teeth using CBCT scans and two angled periapical radiographs. Thirty-two teeth were diagnosed with periapical lesions using conventional radiographs and a further 10 (24\%) with CBCT. When the periapical status of the individual roots of these teeth was assessed, CBCT allowed 38\% more periapical lesions to be detected than with conventional radiographs. CBCT was found to have increased sensitivity for detecting apical periodontitis compared with periapical and panoramic radiography. The sensitivity of periapical and panoramic radiography was found to be 0.55 and 0.28 respectively. CBCT has $100 \%$ specificity (1.0) and sensitivity (1.0) in detecting artificially created periapical lesion in dried human mandibles [7]. Recently a periapical index based on cone beam-computed tomography (CBCTPAI) for identification of apical periodontitis has been proposed. The CBCT PAI is a 6-point (0-5) scoring system calculated from determining the largest lesional measurement in either the buccopalatal, mesio-distal, or axial dimension or taking into account expansion and destruction of cortical bone [8-14] (Table 2).

\section{Assessment of Root and Canal Anatomy}

Knowledge of root canal anatomy and variations between ethnic groups is essential for clinicians to facilitate effective root canal treatment (RCT). Successful endodontic therapy is dependent on identification of all root canals followed by proper cleaning, shaping and obturation of all canals. Most often radiographs may not show the presence of all canals within the root, especially in the buccolingual plane. Such missed canals may be responsible for persistent infection and post treatment disease. The prevalence of a second mesiobuccal 


\begin{tabular}{|c|c|c|c|c|}
\hline Author & Year & Sample & Study & Findings and conclusion \\
\hline Estrela et al. [5] & 2008 & $\begin{array}{l}\text { Endodontically infected } \\
1508 \text { teeth }\end{array}$ & $\begin{array}{l}\text { Comparison of diagnostic } \\
\text { accuracy of panoramic and periapical radiographs with } \\
\text { CBCT for the detection of apical periodontitis }\end{array}$ & $\begin{array}{l}\text { Increased sensitivity of CBCT for } \\
\text { detecting apical periodontitis compared with } \\
\text { periapical and panoramic radiography. }\end{array}$ \\
\hline $\begin{array}{l}\text { Lofthag- } \\
\text { Hansen et al. [6] }\end{array}$ & 2007 & 46 posterior teeth(in vivo & $\begin{array}{l}\text { Compared the periapical status using } \mathrm{CBCT} \text { and } \\
\text { radiographs }\end{array}$ & $\begin{array}{l}\text { CBCT allowed } 38 \% \text { more periapical lesions to be } \\
\text { detected than with conventional radiographs }\end{array}$ \\
\hline Patel et al. [7] & 2009 & 6 molar teeth & $\begin{array}{l}\text { Comparison of the diagnostic accuracy of intraoral digital } \\
\text { periapical radiography with that of cone beam computed } \\
\text { tomography (CBCT) for the detection of artificial } \\
\text { periapical bone defects }\end{array}$ & $\begin{array}{l}\text { CBCT improved the detection of the presence and } \\
\text { absence of artificial periapical lesions }\end{array}$ \\
\hline Low et al. [9] & 2008 & $\begin{array}{l}37 \text { premolars, } 37 \text { molars, } \\
\text { total } 157 \text { roots }\end{array}$ & $\begin{array}{l}\text { Comparison between periapical (PA) radiography } \\
\text { and cone-beam tomography (CBT) for preoperative } \\
\text { diagnosis. }\end{array}$ & $\begin{array}{l}\text { Detecting lesions with PA radiography alone was } \\
\text {.difficult. Additional findings were seen significantly } \\
\text { more frequently in CBCT }\end{array}$ \\
\hline Bornstein et al. [10] & 2011 & 38 molars with 75 roots & $\begin{array}{l}\text { The type of PA lesion as diagnosed on PA radiographs } \\
\text { was compared with the type of lesion seen on sagittal } \\
\text { and coronal CBCT sections. }\end{array}$ & $\begin{array}{l}(25.9 \%) \text { lesions diagnosed with sagittal CBCT slices } \\
\text { were missed with PA radiography. }\end{array}$ \\
\hline Paes da Silva. [11] & 2012 & 300 patients & $\begin{array}{l}\text { Determinationof the prevalence of apical periodontitis } \\
\text { (AP) detected in cone beam CT (CBCT) images from a } \\
\text { database. }\end{array}$ & $\begin{array}{l}\text { Apical Periodontitis can be frequently found in } \\
\text { CBCT examinations CBCT databases are useful } \\
\text { for cross-sectional studies about Apical periodontitis } \\
\text { prevalence in a population. }\end{array}$ \\
\hline Estrela C et al. [12] & 2009 & 1020 teeth & $\begin{array}{l}\text { Assessment of the influence of intracanal post on } \\
\text { apical periodontitis identified by cone-beam computed } \\
\text { tomography. }\end{array}$ & $\begin{array}{l}\text { AP was detected more frequently when CBCT } \\
\text { method was used. }\end{array}$ \\
\hline Moura MS et al. [13] & 2009 & 503 root canals & $\begin{array}{l}\text { Assessment of the influence of length of root canal } \\
\text { obturation on apical periodontitis detected by periapical } \\
\text { radiography and cone beam computed tomography. }\end{array}$ & $\begin{array}{l}\text { Detection of apical periodontitis increased when } \\
\text { CBCT was used. }\end{array}$ \\
\hline Abella F [14] & 2012 & 138 teeth & $\begin{array}{l}\text { Evaluating the Periapical Status of Teeth with Irreversible } \\
\text { Pulpitis by Using Cone-beam Computed Tomography } \\
\text { Scanning and Periapical Radiographs. }\end{array}$ & $\begin{array}{l}\text { The study highlighted the advantages of using CBCT } \\
\text { for detecting AP lesions, especially in teeth with } \\
\text { symptomatic irreversible pulpitis. }\end{array}$ \\
\hline
\end{tabular}

Table 2: Role of CBCT in the detection of apical periodontitis.

\begin{tabular}{|c|c|c|c|c|}
\hline Author & Year & Sample & Study & Findings and conclusion \\
\hline Jojo Kottoor et al. [16] & 2010 & Case report & $\begin{array}{l}\text { Maxillary First Molar with Seven Root Canals } \\
\text { Diagnosed with Cone-Beam Computed Tomography } \\
\text { Scanning }\end{array}$ & $\begin{array}{l}\text { Unusual morphology was confirmed with the help of cone beam } \\
\text { computerized tomography (CBCT) scans }\end{array}$ \\
\hline Zheng et al. [17] & 2011 & 608 teeth & $\begin{array}{l}\text { Evaluation of the anatomical features of C-shaped } \\
\text { canal systems in Chinese mandibular second molars by } \\
\text { cone-beam computed tomography (CBCT). }\end{array}$ & $\begin{array}{l}\text { CBCT is a clinically useful tool in the assessment of additional } \\
\text { distolingual root and "C" shaped canals }\end{array}$ \\
\hline Zhang et al. [18] & 2011 & 389 teeth & $\begin{array}{l}\text { Use of cone beam computed tomography to evaluate } \\
\text { root and canal morphology of mandibular molars in } \\
\text { Chinese individuals }\end{array}$ & $\begin{array}{l}\text { CBCT is an effective tool for the detection of additional } \\
\text { distolingual root and C-shaped root/canals, and it is a valuable } \\
\text { aid for dentists providing root canal treatment. }\end{array}$ \\
\hline Mathrene et al. [19] & 2008 & $\begin{array}{l}72 \text { extracted } \\
\text { teeth }\end{array}$ & $\begin{array}{l}\text { Comparison of CBCT and radiography in identifying } \\
\text { the canal anatomy }\end{array}$ & СВСТ identified more canals which were missed by radiographs \\
\hline Tomoatsu Kaneko [20] & 2011 & Case report & $\begin{array}{l}\text { Non-surgical endodontic treatment of dens invaginatus } \\
\text { with the aid of (CBCT). }\end{array}$ & $\begin{array}{l}\text { CBCT greatly helped the decision of avoiding further intervention } \\
\text { that could have been difficult to negotiate. }\end{array}$ \\
\hline Abella et al. [21] & 2011 & Case report & $\begin{array}{l}\text { Managing severe curvature of radix entomolaris: } \\
\text { three-dimensional analysis with cone beam computed } \\
\text { tomography }\end{array}$ & $\begin{array}{l}\text { CBCT provided more accurate information in terms of } \mathrm{RE} \\
\text { inclination and root canal curvature before commencing root } \\
\text { canal treatment. }\end{array}$ \\
\hline $\begin{array}{l}\text { Je'ro^me Michetti et al. } \\
\text { [22] }\end{array}$ & 2010 & 90 teeth & $\begin{array}{l}\text { Validation of Cone Beam Computed Tomography as a } \\
\text { Tool to Explore Root Canal Anatomy }\end{array}$ & $\begin{array}{l}\text { Strong to very strong correlation was found between the data } \\
\text { acquired by using CBCT and histology }\end{array}$ \\
\hline Patel S [23] & 2010 & Case report & $\begin{array}{l}\text { The use of cone beam computed tomography in the } \\
\text { conservative management of dens invaginatus }\end{array}$ & $\begin{array}{l}\text { The true nature of dens invaginatus cannot always be estimated } \\
\text { from conventional radiographs. Cone beam computed } \\
\text { tomography is a useful diagnostic tool in the management of } \\
\text { dens invaginatus. }\end{array}$ \\
\hline Kottoor J et al. [24] & 2011 & Case report & $\begin{array}{l}\text { Four-rooted maxillary first molar having C-shaped } \\
\text { palatal root canal morphology evaluated using cone- } \\
\text { beam computerized tomography }\end{array}$ & $\begin{array}{l}\text { The evaluation of CBCT images can result in better understanding } \\
\text { of root canal anatomy, which enables the clinician to investigate } \\
\text { the root canal system and to clean, shape, and obturate it more } \\
\text { effectively. }\end{array}$ \\
\hline Kottoor J [25] & 2010 & Case report & $\begin{array}{l}\text { Endodontic management of a maxillary first molar } \\
\text { with eight root canals evaluated using cone-beam } \\
\text { computed tomography scanning }\end{array}$ & $\begin{array}{l}\text { The use of CBCT imaging in endodontically challenging cases } \\
\text { can facilitate a better understanding of the complex root canal } \\
\text { anatomy, which ultimately enables the clinician to explore } \\
\text { the root canal system and clean, shape, and obturate it more } \\
\text { efficiently. }\end{array}$ \\
\hline $\begin{array}{l}\text { Vier-Pelisser FV et al. } \\
\text { [26] }\end{array}$ & 2012 & Case report & $\begin{array}{l}\text { Use of cone beam computed tomography in the } \\
\text { diagnosis, planning and follow up of a type III dens } \\
\text { invaginatus case. }\end{array}$ & $\begin{array}{l}\text { CBCT may aid the diagnosis as well as the management plan } \\
\text { and follow-up of teeth with this developmental anomaly. }\end{array}$ \\
\hline La SH et al. [27] & 2010 & Case report & $\begin{array}{l}\text { Identification of independent middle mesial canal in } \\
\text { mandibular first molar using cone-beam computed } \\
\text { tomography imaging. }\end{array}$ & $\begin{array}{l}\text { This case report highlights the usefulness of CBCT imaging } \\
\text { for accurate diagnosis and management of the unusual canal } \\
\text { morphology. }\end{array}$ \\
\hline
\end{tabular}




\begin{tabular}{|c|c|c|c|c|}
\hline Bernardes RA et al. [28] & 2012 & 34 teeth & $\begin{array}{l}\text { Comparative study of cone beam computed } \\
\text { tomography and intraoral periapical radiographs } \\
\text { in diagnosis of lingual-simulated external root } \\
\text { resorptions. }\end{array}$ & $\begin{array}{l}\text { Cone beam computed tomography showed better diagnostic } \\
\text { ability compared with intraoral radiography, regardless of the } \\
\text { tooth or the dimensions of the resorption evaluated. }\end{array}$ \\
\hline Reis AG [29] & 2013 & $\begin{array}{l}100 \text { patients, } \\
343 \text { teeth }\end{array}$ & $\begin{array}{l}\text { Correlating second canal in mesiobuccal root of } \\
\text { maxillary molars with root third and patient age }\end{array}$ & $\begin{array}{l}\text { The prevalence of MB2 canals was found to decrease as } \\
\text { the root canal approaches the apical third and as age increases. } \\
\text { CBCT scanning proved effective in mapping MB2 canals present } \\
\text { in different thirds of the root. }\end{array}$ \\
\hline Guerrero ME [30] & 2013 & 256 Patients & $\begin{array}{l}\text { Comparison of panoramic radiography and CBCT } \\
\text { to predict postoperative outcome after wisdom tooth } \\
\text { removal }\end{array}$ & $\begin{array}{l}\text { This study concluded that, CBCT was not better than panoramic } \\
\text { radiography in predicting postoperative complications for } \\
\text { moderate-risk cases of impacted third mandibular molars. } \\
\text { Nonetheless, a CBCT buccolingual view can accurately confirm } \\
\text { the number of roots and root morphology of the third molar better } \\
\text { than PA }\end{array}$ \\
\hline Vizzotto MB [31] & 2013 & $\begin{array}{l}89 \text { maxillary } \\
\text { molar teeth }\end{array}$ & $\begin{array}{l}\text { CBCT for the assessment of second mesiobuccal } \\
\text { (MB2) canals in maxillary molar teeth: effect of voxel } \\
\text { size and presence of root filling. }\end{array}$ & $\begin{array}{l}\text { CBCT was associated with higher mean values of specificity } \\
\text { and sensibility than radiographic examination for the detection of } \\
\text { MB2 canals. When endodontic retreatment is necessary removal } \\
\text { of the root filling prior to the CBCT examination eliminates } \\
\text { artifacts. }\end{array}$ \\
\hline
\end{tabular}

Table 3: Role of CBCT in studying the internal anatomy of tooth.

canal (MB2) in maxillary first molars has been reported to vary from $69 \%$ to $93 \%$ depending on the study method employed. Increased number of MB2 canal can be identified with CBCT when compared to conventional radiographs. Recently it was reported diagnosis and management of a maxillary first molar with seven root canals using CBCT. CBCT imaging has also been reported to characterize the high prevalence of the distolingual canal, highlight anomalies in the root canal system of mandibular premolars, and assist in the determination of root curvature. In a study that evaluated 608 permanent mandibular second molars using CBCT a higher prevalence of "C" shaped canals was noticed [15-17]. CBCT is an effective tool for the detection of additional distolingual roots and C-shaped canals [18] (Table 3).

\section{Assessment of Dentoalveolar Trauma}

The exact extent and severity of dentoalveolar traumatic injuries can be assessed with just one scan from which multiple views can be selected and analyzed. Various studies have shown CBCT to be effective in the diagnosis of vertical root fracture when compared with radiograph [32-34]. The diagnostic ability of CBCT in detecting vertical root fracture was not influenced by the presence of posts or gutta-percha [35]. Limited cone beam CT, outperformed the twodimensional intraoral, conventional as well as digital, radiographic methods in detecting simulated horizontal root fracture [32]. CBCT can be an ideal alternative in the diagnosis of root fracture in the field of endodontics. CBCT is also more effective in detecting the alveolar fracture compared to radiographs. As CBCT is an extra-oral technique it is also more comfortable for trauma patients when compared to several intra-oral radiographs. CBCT also increases diagnostic quality and help decrease the potential failure of treatment and/or the prescription of unwarranted dental procedures. It has also been demonstrated that presence of root canal fillings and metallic post may cause streaking artifact which may lower the diagnostic value of CBCT (Table 4).

\begin{tabular}{|c|c|c|c|c|}
\hline Author & Year & Sample & Study & Findings and conclusion \\
\hline Kamburog lu et al. [32] & 2009 & 18 teeth & $\begin{array}{l}\text { Effectiveness of limited cone-beam computed tomography } \\
\text { in the detection of horizontal root } \\
\text { fracture }\end{array}$ & $\begin{array}{l}\text { Limited cone beam CT, outperformed the two-dimensional } \\
\text { intraoral, conventional as well as digital, radiographic } \\
\text { methods in detecting simulated horizontal root fracture. }\end{array}$ \\
\hline Lu-Tang et al. [33] & 2011 & Case report & $\begin{array}{l}\text { Detection of vertical root fracture using cone beam } \\
\text { computed tomography }\end{array}$ & $\begin{array}{l}\text { CBCT imaging is useful in rapid diagnosis of VRFs and } \\
\text { designing of further treatment }\end{array}$ \\
\hline Ping Wang et al. [34] & 2011 & $\begin{array}{l}\text { Report of four } \\
\text { cases }\end{array}$ & $\begin{array}{l}\text { Detection of vertical root fractures in non-endodontically } \\
\text { treated molars using } \\
\text { cone-beam computed tomography }\end{array}$ & CBCT provides more information on the presence of VRFs. \\
\hline Melo SL et al. [35] & 2010 & 180 teeth & $\begin{array}{l}\text { Evaluation of the diagnostic ability of a cone-beam computed } \\
\text { tomography scan to assess longitudinal root fractures in } \\
\text { prosthetically treated teeth }\end{array}$ & $\begin{array}{l}\text { Limited cone-beam CT is more useful than the other } 3 \\
\text { radiographic modalities for diagnostic imaging of horizontal } \\
\text { tooth root fracture. }\end{array}$ \\
\hline Dalili et al. [36] & 2012 & 10 teeth & $\begin{array}{l}\text { To evaluate the value of cone beam CT in detection of } \\
\text { dental root fractures }\end{array}$ & $\begin{array}{l}\text { CBCT shows good potential for use in the detection of } \\
\text { root fracture as it ensures a high level of diagnostic score } \\
\text { accuracy. }\end{array}$ \\
\hline Masoud et al. [37] & 2010 & 100 teeth & $\begin{array}{l}\text { Comparison of CBCT and radiography in detecting vertical } \\
\text { root fractures }\end{array}$ & $\begin{array}{l}\text { CBCT achieves a more accurate diagnosis of vertical root } \\
\text { fracture when compared to radiographs }\end{array}$ \\
\hline P. Wang et al. [38] & 2011 & $\begin{array}{l}128 \text { patients, } \\
138 \text { teeth }\end{array}$ & $\begin{array}{l}\text { Detection of dental root fractures by using cone-beam } \\
\text { computed } \\
\text { Tomography and radiography }\end{array}$ & $\begin{array}{l}\text { CBCT appears to be more accurate than conventional dental } \\
\text { radiography in } \\
\text { the detection of root fractures. }\end{array}$ \\
\hline Zou X et al. [39] & 2011 & $\begin{array}{l}\text { Report of } 3 \\
\text { cases }\end{array}$ & $\begin{array}{l}\text { Evaluation of the ability of cone-beam computerized } \\
\text { tomography to detect vertical root fractures in endodontically } \\
\text { treated and nonendodontically treated teeth }\end{array}$ & $\begin{array}{l}\text { CBCT provided useful information in diagnosing VRFs in both } \\
\text { endodontically treated and nonendodontically treated teeth, } \\
\text { especially when VRFs could not be confirmed by clinical } \\
\text { findings and PRs. }\end{array}$ \\
\hline Hassan B et al. [40] & 2009 & 80 teeth & $\begin{array}{l}\text { Detection of vertical root fractures in endodontically treated } \\
\text { teeth by a cone beam computed tomography scan. }\end{array}$ & $\begin{array}{l}\text { Results showed an overall higher accuracy for CBCT }(0.86) \\
\text { scans than PRs }(0.66) \text { for detecting VRF. }\end{array}$ \\
\hline Ozer SY [41] & 2010 & 80 teeth & $\begin{array}{l}\text { Detection of vertical root fractures of different thicknesses } \\
\text { in endodontically enlarged teeth by cone beam computed } \\
\text { tomography versus digital radiography }\end{array}$ & $\begin{array}{l}\text { CBCT scans are effective for detecting VRFs of different } \\
\text { thicknesses. }\end{array}$ \\
\hline
\end{tabular}




\begin{tabular}{|c|c|c|c|c|}
\hline Edlund $\mathrm{M}$ et al. [42] & 2011 & 29 patients & $\begin{array}{l}\text { Detection of vertical root fractures by using cone-beam } \\
\text { computed tomography }\end{array}$ & $\begin{array}{l}\text { This study revealed the superior diagnostic accuracy of } \\
\text { CBCT for detection of VRF }\end{array}$ \\
\hline Wang P et al. [43] & 2011 & $\begin{array}{l}\text { Report of } 3 \\
\text { cases }\end{array}$ & $\begin{array}{l}\text { Evaluation of horizontal/oblique root fractures in the palatal } \\
\text { roots of maxillary first molars using cone-beam computed } \\
\text { tomography }\end{array}$ & $\begin{array}{l}\text { CBCT might be a useful complementary diagnostic method } \\
\text { to conventional radiography in cases of suspected horizontal/ } \\
\text { oblique root fractures. }\end{array}$ \\
\hline Varshosaz M et al. [44] & 2010 & 100 teeth & $\begin{array}{l}\text { Comparison of conventional radiography with cone beam } \\
\text { computed tomography for detection of vertical root fractures }\end{array}$ & $\begin{array}{l}\text { CBCT was shown to be significantly better than conventional } \\
\text { periapical radiography for diagnosis of vertical root fractures } \\
\text { in vitro }\end{array}$ \\
\hline Bernardes RA et al. [45] & 2009 & 20 patients & $\begin{array}{l}\text { A report of cases that describes the use of cone-beam } \\
\text { volumetric tomography in the diagnosis of root fractures }\end{array}$ & $\begin{array}{l}\text { Cone-beam volumetric tomography was better than } \\
\text { conventional radiography in the diagnosis of root fractures, } \\
\text { thereby constituting an excellent alternative for diagnosis in } \\
\text { general practice. }\end{array}$ \\
\hline Dölekoğlu S et al. [46] & 2010 & Case report & $\begin{array}{l}\text { Diagnosis of jaw and dentoalveolar fractures in a traumatized } \\
\text { patient with cone beam computed tomography }\end{array}$ & $\begin{array}{l}\text { According to } 2 D \text { cephalometric analysis, no fracture existed. } \\
\text { In the diagnosis of dentoalveolar fractures, CBCT has made } \\
\text { it possible for the practitioner to get more detailed information }\end{array}$ \\
\hline Mora MA et al. [47] & 2007 & 60 teeth & $\begin{array}{l}\text { In vitro assessment of local computed tomography for the } \\
\text { detection of longitudinal tooth fractures }\end{array}$ & $\begin{array}{l}\text { Local CT significantly improves the detection of longitudinal } \\
\text { fractures in vitro compared with conventional periapical } \\
\text { radiography. }\end{array}$ \\
\hline Özer SY et al. [48] & 2011 & $\begin{array}{l}\text { Report of three } \\
\text { cases }\end{array}$ & $\begin{array}{l}\text { Diagnosis and treatment of endodontically treated teeth } \\
\text { with vertical root fracture: three case reports with two-year } \\
\text { follow-up. }\end{array}$ & $\begin{array}{l}\text { Cone beam computed tomography-assisted VRF diagnosis } \\
\text { is helpful in detecting fractures; however, higher-resolution } \\
\text { tomography units providing better image quality would be a } \\
\text { better choice for improved visualization of these fractures. }\end{array}$ \\
\hline da Silveira PF [49] & 2013 & $\begin{array}{l}60 \quad \text { single } \\
\text { rooted teeth }\end{array}$ & $\begin{array}{l}\text { Detection of vertical root fractures by conventional } \\
\text { radiographic examination and cone beam computed } \\
\text { tomography }\end{array}$ & $\begin{array}{l}\text { If conventional imaging is not capable to provide adequate } \\
\text { information, CBCT can be indicated if a root fracture is } \\
\text { strongly suspected. }\end{array}$ \\
\hline Avsever H [50] & 2013 & $\begin{array}{l}82 \text { maxillary } \\
\text { incisors }\end{array}$ & $\begin{array}{l}\text { Comparison of intraoral radiography and cone- } \\
\text { beam computed tomography for the detection of } \\
\text { horizontal root fractures. }\end{array}$ & $\begin{array}{l}\text { CBCT imaging offers the clear advantage over conventional } \\
\text { imaging that traumatized teeth can be visualized in all three } \\
\text { dimensions-especially the oro-facial dimension. }\end{array}$ \\
\hline
\end{tabular}

Table 4: Role of CBCT in the management of dento-alveolar trauma.

\begin{tabular}{|c|c|c|c|c|}
\hline Author & Year & Sample & Study & Findings and conclusion \\
\hline R Christiansen et al. [51] & 2009 & 50 patients, 58 teeth & $\begin{array}{l}\text { Periapical radiography and cone beam computed } \\
\text { tomography forassessment of the periapical bone defect } \\
1 \text { week and } 12 \text { months after root-end resection }\end{array}$ & $\begin{array}{l}\text { More remaining defects were detected } 1 \text { year after } \\
\text { periapical surgery on CBCT } \\
\text { images than on periapical radiographs }\end{array}$ \\
\hline $\begin{array}{l}\text { Christos Angelopoulos et } \\
\text { al. [52] }\end{array}$ & 2008 & 68 mandibular canals & $\begin{array}{l}\text { Comparison Between Digital PanoramicRadiography and } \\
\text { Cone-Beam ComputedTomography for the Identification } \\
\text { of theMandibular Canal }\end{array}$ & $\begin{array}{l}\text { The CBCT reformatted panoramic images } \\
\text { outperformed the digital panoramic images in the } \\
\text { identification of the mandibular canal }\end{array}$ \\
\hline Kim TS et al. [53] & 2010 & 12 Human mandibles & $\begin{array}{l}\text { Comparison of cone-beam computed tomography and } \\
\text { direct measurement in the examination of the mandibular } \\
\text { canal and adjacent structures }\end{array}$ & $\begin{array}{l}\text { Can be used to measure distances from the apices } \\
\text { of the posterior teeth to the mandibular canal as } \\
\text { accurately as direct anatomic dissection }\end{array}$ \\
\hline Shekhar V [54] & 2013 & Case report & $\begin{array}{l}\text { Cone beam computed tomography evaluation of the } \\
\text { diagnosis, treatment planning, and long-term followup of } \\
\text { large periapical lesions treated by endodontic surgery }\end{array}$ & $\begin{array}{l}\text { It was concluded that CBCT was a useful modality } \\
\text { in making the diagnosis and treatment plan and } \\
\text { assessing the outcome of endodontic surgery for } \\
\text { large periapical lesions. }\end{array}$ \\
\hline
\end{tabular}

Table 5: Role of СBCT in endodontic surgical planning

\section{Role of CBCT in Endodontic Surgical Planning}

CBCT may play an important role in periapical surgery. The distance between the cortical plate and the root apex could be measured, and the presence or absence of the maxillary sinus between the roots could be assessed. Location of the lesion, position of the roots with in the bone, and the proximity of vital structures including the inferior alveolar nerve, mental foramen, maxillary sinus, and nasal cavity can be assessed. The true size, location and extent of the periapical lesion can also be appreciated. The cancellous bone pattern, fenestrations, as well as the inclination of the roots of teeth planned for surgery can be accurately determined preoperatively. Root morphology and bony topography can be visualized in three-dimensions, as can the number of root canals and whether they converge or diverge from each other (Table 5).

\section{Assessment of Root Resorption}

Treatment of resorption can be complex and unpredictable. Imaging is critical for accurate diagnosis and appropriate treatment .Conventional radiography does not provide the true and full representation of the lesion. CBCT has been shown to help and determine the treatment complexity as well as aid the clinician in offering an accurate prognosis on the basis of the extent of the resorptive lesion. As a result, both treatment and treatment outcomes are likely to become more predictable (Table 6).

\section{Dental Anomalies}

Anatomic variations should be carefully observed and considered during the diagnosis and treatment planning of teeth with anomalies in order to enhance the chances of success. The use of cone beam computed tomography (CBCT) is very helpful in endodontic diagnosis of complex anatomic variations. Root canal treatment of teeth with complex root canal anatomy such as dens invaginatus, fused root, talon's cusp, etc, can be problematic because infected pulpal tissues may be in inaccessible areas of the canal system. Cleaning and debridement of such root canal systems are therefore challenging. Conventional radiographs have limited role in the assessment of complex root canal morphologies. These modalities, however, do not provide detailed information of the complexity as a result of their inherent limitations. This calls for the use of more advanced imaging modalities such 
Citation: Meena N, Kowsky RD (2014) Applications of Cone Beam Computed Tomography in Endodontics: AReview. Dentistry 4:242. doi:10.4172/21611122.1000242

\begin{tabular}{|c|c|c|c|c|}
\hline Author & Year & Sample & Study & Findings and conclusion \\
\hline S. Patel [55] & 2009 & 15 teeth & $\begin{array}{l}\text { Comparison of accuracy of intraoral periapical } \\
\text { radiography with cone beam computed tomography } \\
(\mathrm{CBCT}) \text { for the detection and management of resorption } \\
\text { lesions. }\end{array}$ & $\begin{array}{l}\mathrm{CBCT} \text { was effective and reliable in detecting the } \\
\text { presence of resorption lesions }\end{array}$ \\
\hline K. Kamburog lu et al. [56] & 2010 & 60 teeth & $\begin{array}{l}\text { Comparison of the diagnostic accuracy of CBCT images of } \\
\text { different voxel resolutions used to detect simulated small } \\
\text { internal resorption cavities }\end{array}$ & $\begin{array}{l}\text { Ultra-and high-resolution CBCT images performed } \\
\text { similarly and better than low-resolution images in the } \\
\text { detection of simulated internal resorption ex vivo. }\end{array}$ \\
\hline V. S. H. Yu et al. [57] & 2010 & Case report & Case report on multiple idiopathic cervical resorption & $\begin{array}{l}\text { CBCT demonstrated that the lesions were more } \\
\text { extensive and more widely distributed than was seen } \\
\text { using conventional radiography. }\end{array}$ \\
\hline Roberto Estevez et al. [58] & 2010 & Case reprt & $\begin{array}{l}\text { Invasive Cervical Resorption Class III managed using the aid } \\
\text { of CBCT }\end{array}$ & $\begin{array}{l}\text { CBCT is a very useful tool to achieve proper diagnosis } \\
\text { and management of cervical resorption. }\end{array}$ \\
\hline $\begin{array}{l}\text { Kivanc, Kamburo_glu, et al. } \\
\text { [59] }\end{array}$ & 2011 & 50 teeth & $\begin{array}{l}\text { Observer Ability to Detect Ex Vivo Simulated Internal or } \\
\text { External Cervical Root Resorption }\end{array}$ & $\begin{array}{l}\text { High-resolution } \\
\text { CBCT images performed better than film in the ex vivo } \\
\text { detection and localization of simulated internal and } \\
\text { external cervical root resorption. }\end{array}$ \\
\hline Estrela C et al. [60] & 2009 & 40 patients & $\begin{array}{l}\text { Method to evaluate inflammatory root resorption by using } \\
\text { cone beam computed tomography }\end{array}$ & $\begin{array}{l}\text { CBCT seems to be useful in the evaluation of internal } \\
\text { root resorption, and its diagnostic performance was } \\
\text { better than that of periapical radiography. }\end{array}$ \\
\hline Bhuva B et al. [61] & 2011 & Case report & $\begin{array}{l}\text { The use of limited cone beam computed tomography in the } \\
\text { diagnosis and management of a case of perforating internal } \\
\text { root resorption. }\end{array}$ & $\begin{array}{l}\text { This case report describes the use of CBCT in } \\
\text { the diagnosis and treatment planning of a case of } \\
\text { perforating internal root resorption. }\end{array}$ \\
\hline Shokri A [62] & 2013 & 54 teeth & $\begin{array}{l}\text { Diagnosis of simulated external root resorption using } \\
\text { conventional intraoral film radiography, CCD, PSP, and CBCT }\end{array}$ & $\begin{array}{l}\text { For locations of root resorption, significant differences } \\
\text { were found between CBCT and other methods in the } \\
\text { apical regions. CBCT was only useful for detection } \\
\text { of cavities located in the apical one-third of the root, } \\
\text { compared to other digital or conventional methods }\end{array}$ \\
\hline Castro IO [63] & 2013 & $\begin{array}{lr}1256 & \text { roots } \\
\text { from } & 30 \\
\text { Patients } & \end{array}$ & $\begin{array}{l}\text { Evaluation of apical root resorption due to orthodontic } \\
\text { treatment detected by cone beam computed tomography }\end{array}$ & $\begin{array}{l}\text { The results of this investigation showed that CBCT was } \\
\text { effective for detecting in vivo even minimal degrees of } \\
\text { ARR due to orthodontic treatment and allowed three- } \\
\text { dimensional evaluation of dental roots and visualization } \\
\text { of palatine roots of maxillary molars. }\end{array}$ \\
\hline
\end{tabular}

Table 6: Role of $\mathrm{CBCT}$ in the management of root resorption.

\begin{tabular}{|c|c|c|c|c|}
\hline Author & Year & Sample & Study & Findings and conclusion \\
\hline Kfir A [64] & 2013 & Case report & $\begin{array}{l}\text { Management of complex type } 3 \text { dens } \\
\text { invaginatususing cone beam computed } \\
\text { tomography }(\mathrm{CBCT}) \text { and 3D plastic models. }\end{array}$ & $\begin{array}{l}\text { CBCT is a diagnostic tool that may allow for the management of such teeth with } \\
\text { complex anatomy. } 3 \mathrm{D} \text { printed models may be a valuable aid in the process of } \\
\text { assessing and planning effective treatment modalities and practicing them ex } \\
\text { vivo before actually performing the clinical procedure. }\end{array}$ \\
\hline Pradeep k [65] & 2012 & Case report & $\begin{array}{l}\text { Management of Type III dens in denteUsing } \\
\text { Cone Beam Computed Tomography. }\end{array}$ & $\begin{array}{l}\text { Periapical radiographs are limited in revealing the type, extension, and } \\
\text { complex morphology of dens invaginatus, as well as the actual bone loss. The } \\
\text { reconstructed images from the CBCT data are particularly useful in assessing the } \\
\text { true nature of the invagination, in particular, the relationship of the invagination } \\
\text { with the root canal. }\end{array}$ \\
\hline Narayana P [66] & 2012 & Case report & $\begin{array}{l}\text { Management of a dens invaginatuscase by } \\
\text { using a unique treatment approach }\end{array}$ & $\begin{array}{l}\text { Endodontic clinical management of a tooth with dens invaginatus may be } \\
\text { benefited by the inclusion of cone-beam computed tomography (CBCT) to aid in } \\
\text { the diagnosis and treatment-planning phase }\end{array}$ \\
\hline Vier-Pelisser FV [26] & 2012 & Case report & $\begin{array}{l}\text { Use of cone beam computed tomography in } \\
\text { the diagnosis, planning and follow up of a } \\
\text { type III dens invaginatus case. }\end{array}$ & $\begin{array}{l}\text { In this case the CBCT scans revealed that the periapical radiolucency was } \\
\text { significantly larger than seen radiographically as well as an increased thickness } \\
\text { of the buccal cortical plate. The authors concluded that CBCT may aid the } \\
\text { diagnosis as well as the management plan and follow-up of teeth with this (Dens } \\
\text { invaginatus) developmental anomaly. }\end{array}$ \\
\hline Kaneko T [20] & 2011 & Case report & $\begin{array}{l}\text { Management of dens invaginatus in a } \\
\text { maxillary lateral incisor with the aid of cone- } \\
\text { beam computed tomography }\end{array}$ & $\begin{array}{l}\text { CBCT scan demonstrated inaccessible and unfilled canal and invagination areas } \\
\text { because of complex internal morphology characterized by (i) C- or ring-shaped } \\
\text { cross-sectional canal configuration with constrictions at different points in different } \\
\text { root levels and (ii) a prominent intraradicular cavity that was communicated with } \\
\text { the enamel-lined invagination and opened into the apical periodontium. CBCT } \\
\text { is useful in the assessment of the feasibility in the treatment of dens invaginatus. }\end{array}$ \\
\hline Durack C [67] & 2011 & Case report & $\begin{array}{l}\text { Use of cone beam computed tomography } \\
\text { in the management of dens invaginatus } \\
\text { affecting a strategic tooth in a patient } \\
\text { affected by hypodontia }\end{array}$ & $\begin{array}{l}\text { The CBCT images facilitated the appropriate } \\
\text { positioning of these orifices and provided valuable information regarding safe } \\
\text { cavity dimensions and angulations. The authors concluded that, in this case, it } \\
\text { is unlikely that endodontic treatment could have been as accurately planned } \\
\text { and delivered as safely and successfully as it was without the aid of the CBCT } \\
\text { images. }\end{array}$ \\
\hline Patel S [68] & 2010 & Case report & $\begin{array}{l}\text { Use of cone beam computed tomography } \\
\text { in the conservative management of dens } \\
\text { invaginatus }\end{array}$ & $\begin{array}{l}\text { The true nature of dens invaginatus cannot always be estimated from conventional } \\
\text { radiographs. Cone beam computed tomography is a useful diagnostic tool in } \\
\text { the management of dens invaginatus. The reconstructed images from the CBCT } \\
\text { data were particularly useful in assessing the true nature of the } \\
\text { invagination, in particular, the relationship of the invagination with the root canal. }\end{array}$ \\
\hline
\end{tabular}




\begin{tabular}{|c|c|c|c|c|}
\hline Baratto-Filho F [23] & 2012 & Case report & $\begin{array}{l}\text { Multidisciplinary treatment involving a } \\
\text { permanent maxillary lateral incisor fused to } \\
\text { a supernumerary tooth with pulp necrosis } \\
\text { and periapical lesion }\end{array}$ & $\begin{array}{l}\text { CBCT scan and an operative } \\
\text { microscope may help the diagnosis and facilitate root canal localization in cases } \\
\text { of complex and varied morphology. In the present case, CBCT was performed to } \\
\text { have a more detailed view of the complex root canal system morphology since } \\
\text { CBCT enables three dimensional } \\
\text { image reconstruction }\end{array}$ \\
\hline Jaya R [69] & 2013 & Case report & $\begin{array}{l}\text { Dilated invaginated odontome with talon } \\
\text { cusp in a permanent maxillary central } \\
\text { incisor diagnosed by cone beam computed } \\
\text { tomography. }\end{array}$ & $\begin{array}{l}\text { CBCT was useful in the interpretation of this complex tooth anomaly in multiple } \\
\text { slices along the three axes. The reconstructed } 3 D \text { CBCT images of the involved } \\
\text { tooth revealed a complex structure comprising a ring-like formation of the } \\
\text { root. The CBCT axial images revealed the pulp space to be compressed and } \\
\text { discontinuous within the ring. As the CBCT revealed a very complex root canal } \\
\text { anatomy not amenable to successful cleaning and shaping, the choice of surgical } \\
\text { or non-surgical endodontics was ruled out and the tooth was extracted. }\end{array}$ \\
\hline Kobayashi TY [70] & 2013 & Case report & $\begin{array}{l}\text { Usefulness of cone beam computed } \\
\text { tomography for treatment of complex } \\
\text { odontoma. }\end{array}$ & $\begin{array}{l}\text { In this case report, СВСT analysis enabled an accurate diagnosis of the } \\
\text { localisation, extension, internal structure of the lesion, and } \\
\text { the additional diagnosis of an impacted supernumerary tooth. }\end{array}$ \\
\hline Liang RZ [71] & 2012 & Case report & $\begin{array}{l}\text { Endodontic therapy of maxillary fused } \\
\text { second and third molars, using cone-beam } \\
\text { computed tomography }\end{array}$ & $\begin{array}{l}\text { CBCT images clearly demonstrated the presence of fusion of the maxillary molars } \\
\text { and the numbers, positions and morphologies of all root canals associated with } \\
\text { each tooth. Examination of the CBCT images showed three slightly curved and } \\
\text { patent root canals present in the maxillary second molar and a similar single } \\
\text { canal in the fused third molar that merged with the distobuccal canal of the } \\
\text { second molar. }\end{array}$ \\
\hline Song CK [72] & 2010 & Case report & $\begin{array}{l}\text { Endodontic management of supernumerary } \\
\text { tooth fused with maxillary first molar by } \\
\text { using cone-beam computed tomography. }\end{array}$ & $\begin{array}{l}\text { In this case report, an iatrogenic communication between the maxillary first } \\
\text { molar and the supernumerary tooth was observed in the CBCT image and was } \\
\text { repaired by using flowable resin. The authors concluded that proper diagnosis } \\
\text { and treatment planning for endodontic management of fused teeth by using } \\
\text { CBCT can ensure predictable and successful results. }\end{array}$ \\
\hline
\end{tabular}

Table 7: Role of CBCT in the management of dental anomalies.

as $\mathrm{CBCT}$, which can help the clinician in making a more accurate diagnosis. CBCT may aid the diagnosis as well as the treatment plan and follow-up of teeth with developmental anomalies. CBCT is a useful adjunct to the clinician's armamentarium in the endodontic treatment of anomalous tooth (Table 7).

To summerize, CBCT appears to be promising in the assessment and treatment of complex endodontic conditions such as:

a) Detection of suspected additional canals and unusual root and canal anatomy based on radiographic examination.

b) To assess the location and severity of root resorption. External and internal resorptions can be easily differentiated with CBCT.

c) To study the root canal system anomalies and for determination of direction and angulation of root curvature

d) To assess the dimensions of lesion or defect and its spatial relationship with vital structures before performing surgical endodontics

e) $\mathrm{CBCT}$ also plays vital role in the detection and management of dento-alveolar traumatic injuries, assessment of endodontic treatment complications, such as overextended root canal fillings, separated instruments, presence of denticles and diffuses calcification, and detection of iatrogenic perforations.

\section{Limitations of CBCT}

While the CBCT has documented advantages over other techniques, there are a few limitations that are reported. At present the images produced with CBCT technology do not have the resolution of conventional radiographs. The spatial resolution of conventional direct-action packet film and digital sensors is in the order of 1520 line pairs $/ \mathrm{mm}$ ) [72]. CBCT images only have a spatial resolution of 2 line pairs $/ \mathrm{mm}$ ) [73]. However, the ability of this technology to demonstrate geometrically accurate images in all three dimensions and the elimination of anatomic noise facilitates the assessment of a number of features important in endodontic diagnosis, treatment, and long-term management. One significant problem, which can affect the image quality and diagnostic accuracy of CBCT images is the scatter and beam hardening caused by high density neighboring structures, such as enamel, metal posts and restorations. If this scattering and beam hardening is associated close to or with the tooth being assessed, the resulting $\mathrm{CBCT}$ images may be of minimal diagnostic value. In clinical Endodontic practice, CBCT scanners with a limited field of view might provide clearer images as they can avoid scanning structures outside the region of interest susceptible to beam hardening (e.g., metallic restorations, dental implants). Endodontic sealers have also been reported to produce artifacts that mimic fracture line. Reduction of voxel size has been suggested to minimize such artifacts. Women of childbearing age must be screened for pregnancy. In case of pregnancy, the benefits of performing a CBCT scan must be weighed against the possible risk to the fetus. But it should be remembered that, since the horizontal trajectory of the CBCT beam through the patient's jaw suggests that the patient's fetus would not be subjected to any direct radiation, and that the only exposure the fetus would receive would be from scattered radiation which is negligible, pregnancy is not an absolute contraindication for performing CBCT scan. Till date there are no reported fetal consequences due to $\mathrm{CBCT}$ scanning during pregnancy. Even though the exposure from $\mathrm{CBCT}$ is significantly less than that of Medical CT, it still utilizes ionizing radiation, hence a CBCT scan should be performed only if there is possibility that the scan would reveal additional important information not gained with conventional radiographs. Finally, scan durations are lengthy at 15-20 s and require the patient to stay absolutely still during that period.

\section{Conclusion}

Conventional radiographs have been used in endodontic practice for varied purposes. Radiography has its limitations in the form of anatomic superimposition, compression of three dimensional anatomy, geometric distortion, etc. Most of these limitations are overcome with the advent of three dimensional CBCT.CBCT has established itself as a highly useful tool in visualizing the exact root and canal anatomy, pathologic alterations, assessment or dentoalveolar trauma, 
surgical assessment, assessment of root resorptions. Knowledge about CBCT will help clinicians to make the full use of this excellent three dimensional imaging system, starting from diagnosis to treatment outcome evaluation.

\section{References}

1. Scarfe WC, Farman AG (2008) What is Cone-Beam CT and How Does it Work? Dent Clin N Am 52: 707-730.

2. Arai Y, Honda K, Iwai K, Shinoda K (2001) Practical model '3DX' of limited cone-beam X-ray CT for dental use. International Congress Series 2001: 713718.

3. Moshiri M, Scarfe WC, Hilgers ML, Scheetz JP, Silveira AM, et al. (2007) Accuracy of linear measurements from imaging plate and lateral cephalometric images derived from cone-beam computed tomography. Am J Orthod Dentofacial Orthop 132: 550-560. 4. Ludlow JB (2008) Dosimetry of KODAK 9000 3D Small FOV CBCT and Panoramic Unit. University of North Carolina, School of Dentistry, Chapel Hill, NC, USA.

4. Estrela C, Bueno MR, Leles CR, Azevedo B, Azevedo JR (2008) Accuracy of cone beam computed tomography and panoramic radiography for the detection of apical periodontitis. J Endod 34: 273-279.

5. Lofthag-Hansen S, Huumonen S, Gro“ndahl K, Gro"ndahl HG 2007) Limited cone-beam CT and intraoral radiography for the diagnosis of periapical pathology. Oral Surg Oral Med Oral Pathol Oral Radiol Endod 103: 114-119.

6. Patel S, Dawood A, Mannocci F, Wilson R, Pitt Ford T (2009) Detection of periapical bone defects in human jaws using cone beam computed tomography and intraoral radiography. Int Endod J 42: 507-515.

7. Estrela C, Bueno MR, Azevedo BC, Azevedo JR, Pécora JD (2008) A new periapical index based on cone beam computed tomography. J Endod 34: 1325-1331.

8. Low MTL, Dula KD, Bu“ rgin W, von Arx T (2008) Comparison of periapical radiography and limited cone-beam tomography in posterior maxillary teeth referred for apical surgery. J Endod 34: 557-562.

9. Bornstein MM, Lauber R, Sendi P, von Arx T (2011) Comparison of periapical and limited cone-beam computed tomography in mandibular molars for analysis of anatomical landmarks before apical surgery. J Endod 37: 151-157.

10. Paes da Silva Ramos Fernandes L, Ordinola-Zapata R, Húngaro Duarte $M$ Alvares Capelozza A (2012) Prevalence of apical periodontitis detected in cone beam CT images of a Brazilian subpopulation. Dentomaxillofac Radio 42: 80179163 .

11. Estrela C, Bueno MR, Porto OC, Rodrigues CD, Pécora JD (2009) Influence of intracanal post on apical periodontitis identified by cone-beam computed tomography. Braz Dent J 20: 370-375.

12. Moura MS, Guedes OA, De Alencar AH, Azevedo BC, Estrela C (2009) Influence of length of root canal obturation on apical periodontitis detected by periapical radiography and cone beam computed tomography. J Endod 35: 805-809.

13. Abella F, Patel S, Duran-Sindreu F, Mercadé M, Bueno R, et al. (2012) Evaluating the Periapical Status of Teeth with Irreversible Pulpitis by Using Cone-beam Computed Tomography Scanning and Periapical Radiographs. J Endod 38: 1588-1591.

14. Abella F, Patel S, Durán-Sindreu F, Mercadé M, Bueno R, et al. (2014) An evaluation of the periapical status of teeth with necrotic pulps using periapical radiography and cone-beam computed tomography. Int Endod J 47: 387-396.

15. Kottoor J, Velmurugan N, Sudha R, Hemamalathi S (2010) Maxillary First Molar with Seven Root Canals Diagnosed with Cone-Beam Computed Tomography Scanning: A Case Report. J Endod 36: 915-921.

16. Zheng Q, Zhang L, Zhou X, Wang Q, Wang Y, et al. (2011) C-shaped roo canal system in mandibular second molars in a Chinese population evaluated by cone-beam computed tomography. Int Endod J 44: 857-862.

17. Zhang R, Wang H, Tian YY, Yu X, Hu T, et al. (2011) Use of cone-beam computed tomography to evaluate root and canal morphology of mandibular molars in Chinese individuals. Int Endod J 44: 990-999.

18. Matherne RP, Angelopoulos C, Kulilid JC, Tira D (2008) Use of cone-beam computed tomography to identify root canal systems in vitro. J Endod 34: 8789.
19. Kaneko T, Sakaue H, Okiji T, Suda H (2011) Clinical management of dens invaginatus in a maxillary lateral incisor with the aid of conebeam computed tomography - a case report. Dent Traumatol 27: 478-483

20. Abella F, Mercadé M, Duran-Sindreu F, Roig M (2011) Managing severe curvature of radix entomolaris: three-dimensional analysis with cone beam computed tomography. Int Endod J 44: 876-885.

21. Michetti J, Maret D, Mallet JP, Diemer F (2010) Validation of cone beam computed tomography as a tool to explore root canal anatomy. J Endod 36 1187-1190.

22. Patel S (2010) The use of cone beam computed tomography in the conservative management of dens invaginatus: a case report. Int Endod J 43: 707-713.

23. Kottoor J, Velmurugan N, Ballal S, Roy A (2011) Four-rooted maxillary first molar having C-shaped palatal root canal morphology evaluated using conebeam computerized tomography: a case report. Oral Surg Oral Med Oral Pathol Oral Radiol Endod 111: e41-45.

24. Kottoor J, Velmurugan N, Surendran S (2011) Endodontic management of a maxillary first molar with eight root canal systems evaluated using cone-beam computed tomography scanning: a case report. J Endod 37: 715-719.

25. Vier-Pelisser FV, Pelisser A, Recuero LC, Só MV, Borba MG, et al. (2012) Use of cone beam computed tomography in the diagnosis, planning and follow up of a type III dens invaginatus case. Int Endod J 45: 198-208.

26. La SH, Jung DH, Kim EC, Min KS (2010) Identification of independent middle mesial canal in mandibular first molar using cone-beam computed tomography imaging. J Endod 36: 542-545.

27. Bernardes RA, de Paulo RS, Pereira LO, Duarte MA, Ordinola-Zapata R et al. (2012) Comparative study of cone beam computed tomography and intraoral periapical radiographs in diagnosis of lingual-simulated external root resorptions. Dent Traumatol 28: 268-272.

28. Reis AG, Grazziotin-Soares R, Barletta FB, Fontanella VR, Mahl CR (2013) Second canal in mesiobuccal root of maxillary molars is correlated with root third and patient age: a cone-beam computed tomographic study.

29. J Endod 39: 588-592.

30. Guerrero ME, Botetano R, Beltran J, Horner K, Jacobs R (2013) Can preoperative imaging help to predict postoperative outcome after wisdom tooth removal? A randomized controlled trial using panoramic radiography versus cone-beam CT. Clin Oral Investig 18: 335-342.

31. Vizzotto MB, Silveira PF, Arús NA, Montagner F, Gomes BP, et al. (2013) CBCT for the assessment of second mesiobuccal canal in maxillary molar teeth: effect of vocal size and presence of root fillings. Int Endod J 46: 870-876.

32. Kamburoğlu K, Ilker Cebeci AR, Gröndahl HG (2009) Effectiveness of limited cone-beam computed tomography in the detection of horizontal root fracture. Dent Traumatol 25: 256-261.

33. Tang L, Zhou XD, Wang Y, Zhang L, Zheng QH, et al. (2011) Detection of vertical root fracture using cone beam computed tomography: report of two cases. Dent Traumatol 27: 484-488.

34. Ping Wang, Wenxi He, Hantang Sun, Qun Lu, Longxing Ni (2012) Detection of vertical root fractures in non-endodontically treated molars using cone-beam computed tomography: a report of four representative cases. Dent Traumatol 28: $329-333$

35. Melo SL, Bortoluzzi EA, Abreu M Jr, Corrêa LR, Corrêa M (2010) Diagnostic ability of a cone-beam computed tomography scan to assess longitudinal root fractures in prosthetically treated teeth. J Endod 36: 1879-1882.

36. Kajan ZD, Taromsari M (2012) Value of cone beam CT in detection of dental root fractures. Dentomaxillofac Radiol 41: 3-10.

37. Varshosaz M, Tavokoli MA, Mostafavi M, Baghban AA (2010) Comparison of conventional radiography with cone beam computed tomography for the detection of vertical root frature. An in vitro study. J Oral Sci 52: 593-597.

38. Wang P, Yan XB, Lui DG, Zhang WL, Zhang Y, et al. (2011) Detection of dental root fractures by using cone-beam computed tomography. Dentomaxillofac Radiol 40: 290-298.

39. Zou X, Liu D, Yue L, Wu M (2011) The ability of cone-beam computerized tomography to detect vertical root fractures in endodontically treated and nonendodontically treated teeth: a report of 3 cases. Oral Surg Oral Med Oral Pathol Oral Radiol Endod 111: 797-801. 
40. Hassan B, Metska ME, Ozok AR, van der Stelt P, Wesselink PR (2009) Detection of vertical root fractures in endodontically treated teeth by a cone beam computed tomography scan. J Endod 35: 719-722.

41. Ozer SY (2010) Detection of vertical root fractures of different thicknesses in endodontically enlarged teeth by cone beam computed tomography versus digital radiography. J Endod 36: 1245-1249.

42. Edlund M, Nair MK, Nair UP (2011) Detection of vertical root fractures by using cone-beam computed tomography: a clinical study. J Endod 37: 768-772.

43. Wang P, He W, Sun H, Lu Q, Ni L (2011) Evaluation of horizontal/oblique root fractures in the palatal roots of maxillary first molars using cone-beam computed tomography: a report of three cases. Dent Traumatol 27: 464-467.

44. Bernardes RA, de Moraes IG, Húngaro Duarte MA, Azevedo BC, de Azevedo JR, et al. (2009) Use of cone-beam volumetric tomography in the diagnosis of root fractures. Oral Surg Oral Med Oral Pathol Oral Radiol Endod 108: 270-277.

45. Dölekoğlu S, Fişekçioğlu E, Ilgüy D, Ilgüy M, Bayirli G (2010) Diagnosis of jaw and dentoalveolar fractures in a traumatized patient with cone beam computed tomography. Dent Traumatol 26: 200-203.

46. Mora MA, Mol A, Tyndall DA, Rivera EM (2007) In vitro assessment of local computed tomography for the detection of longitudinal tooth fractures. Oral Surg Oral Med Oral Pathol Oral Radiol Endod 103: 825-829.

47. Özer SY, Ünlü G, Değer Y (2011) Diagnosis and treatment of endodontically treated teeth with vertical root fracture: three case reports with two-year followup. J Endod 37: 97-102.

48. da Silveira PF, Vizzotto MB, Liedke GS, da Silveira HL, Montagner F, et al. (2013) Detection of vertical root fracture by conventional radiographic examination and cone beam computed tomography- an in vitro analysis. Dent Traumatol 29: 41-46.

49. Avsever H, Gunduz K, Orhan K, Uzun I, Ozmen B, et al. (2013) Comparison of intra-oral radiography and cone beam computed tomography for the detection of horizontal root fractures: an in vitro study. Clin Oral Investig 18: 285-292.

50. Christiansen R, Kirkevang LL, Gotfredsen E, Wenzel A (2009) Periapical radiography and cone beam computed tomography for assessment of the periapical bone defect 1 week and 12 months after root-end resection. Dentomaxillofac Radiol 38: 531-536

51. Angelopoulos C, Thomas S, Hechler S, Parissis N, Hlavacek M (2008) Comparison Between Digital Panoramic Radiography and Cone-Beam Computed Tomography for the Identification of the Mandibular Canal as Part of Presurgical Dental Implant Assessment. J Oral Maxillofac Surg 66: 2130-2135.

52. Kim TS, Caruso JM, Christensen H, Torabinejad M (2010) A comparison of cone-beam computed tomography and direct measurement in the examination of the mandibular canal and adjacent structures. J Endod 36: 1191-1194.

53. Shekhar V, Shashikala K (2013) Comne beam computed tomographic imaging of the diagnosis, treatment planning, and long term follow up of large periapical lesion treated by endodontic surgery: two case reports. Case Rep Dent 2013 564392.

54. Patel S, Dawood A, Wilson R, Horner K, Mannocci F (2009) The detection and management of root resorption lesions using intraoral radiography and cone beam computed tomography - an in vivo investigation. Int Endod J 42: 831838

55. Kamburoğlu K, Kursun S (2010) A comparison of the diagnostic accuracy of CBCT images of different voxel resolutions used to detect simulated smal internal resorption cavities. Int Endod J 43: 798-807.

56. Yu VS, Messer HH, Tan KB (2011) Multiple idiopathic cervical resorption: case report and discussion of management options. Int Endod 44: 77-85.

57. Estevez R, Aranguren J, Escorial A, de Gregorio C, De La Torre F, et al. (2010) Invasive Cervical Resorption Class III in a Maxillary Central Incisor: Diagnosis and Follow-up by Means of Cone-Beam .Computed Tomography. J Endod 36 2012-2014.

58. Kamburoğlu K, Kurşun S, Yüksel S, Oztaş B (2011) Observer Ability to Detect
Ex Vivo Simulated Internal or External Cervical Root Resorption. J Endod 37 : 168-175.

59. Estrela C, Bueno MR, De Alencar AH, Mattar R, Valladares Neto J, et al. (2009) Method to evaluate inflammatory root resorption by using cone beam computed tomography. J Endod 35: 1491-1497.

60. Bhuva B, Barnes JJ, Patel S (2011) The use of limited cone beam computed tomography in the diagnosis and management of a case of perforating internal root resorption. Int Endod J 44: 777-786.

61. Shokri A, Mortazavi H, Salemi F, Javadian A, Bakhtiari H, et al. (2013) Diagnosis of simulated external root resorption using conventional film radiography, $C C D$, PSP, and CBCT: a comparison study. Biomed J 36: 18-22.

62. Castro IO, Alencar AH, Valladares-Neto J, Estrela C (2013) Apical root resorption due to orthodontic treatment detected by cone beam computed tomography. Angle Orthod 83: 196-203.

63. Kfir A, Telishevsky-Strauss Y, Leitner A, Metzger Z (2013) The diagnosis and conservative treatment of a complex type 3 dens invaginatus using cone beam computed tomography(CBCT) and 3D plastic models. Int Endod J 46: 275-288.

64. Pradeep K, Charlie M, Kuttappa MA, Rao PK (2012) Conservative Management of Type III Dens in Dente Using Cone Beam Computed Tomography. J Clin Imaging Sci 2: 51.

65. Narayana P, Hartwell GR, Wallace R, Nair UP (2012) Endodontic clinical management of a dens invaginatus case by using a unique treatment approach: a case report. J Endod 38: 1145-1148.

66. Durack C, Patel S (2011) The use of cone beam computed tomography in the management of dens invaginatus affecting a strategic tooth in a patient affected by hypodontia: a case report. Int Endod J 44: 474-483.

67. Baratto-Filho F, Leonardi DP, Crozeta BM, Baratto SP, Campos EA, et al. (2012) The challenges of treating a fused tooth. Braz Dent J 23: 256-262.

68. Jaya R, Mohan Kumar RS, Srinivasan R (2013) A rare case of dilated invaginated odontome with talon cusp in a permanent maxillary central incisor diagnosed by cone beam computed tomography. Imaging Sci Dent 43: 209213

69. Kobayashi TY, Gurgel CV, Cota AL, Rios D, Machado MA, et al. (2013) The usefulness of cone beam computed tomography for treatment of complex odontoma. Eur Arch Paediatr Dent 14: 185-189.

70. Liang RZ, Wu JT, Wu YN, Smales RJ, Hu M, et al. (2012) Bilateral maxillary fused second and third molars: a rare occurrence. Int J Oral Sci 4: 231-234.

71. Song CK, Chang HS, Min KS (2010) Endodontic management of supernumerary tooth fused with maxillary first molar by using cone-beam computed tomography. J Endod 36: 1901-1904.

72. Farman AG, Farman TT (2005) A comparison of 18 different X-ray detectors currently used in dentistry. Oral Surgery, Oral Surg Oral Med Oral Pathol Oral Radiol Endod 99: 485-489.

73. Yamamoto K, Ueno K, Seo K, Shinohara D (2003) Development of dentomaxillofacial cone beam X-ray computed tomography system. Orthod Craniofac Res 6: 160-162. 